\title{
THERAPEUTIC PLASMA EXCHANGE AND DOUBLE FILTRATION PLASMAPHERESIS IN SEVERE NEUROIMMUNE DISORDERS
}

\author{
Corina Roman-Filip ${ }^{1,2}$, Maria-Gabriela Catană ${ }^{2}$, Alina Bereanu ${ }^{1}$, Ana Lăzăroae ${ }^{2}$, \\ Felicia Gligor ${ }^{1}$ and Mihai Sava ${ }^{1,3}$ \\ ${ }^{1}$ Lucian Blaga University, Faculty of Medicine, Sibiu, Romania; \\ ${ }^{2}$ Department of Neurology, University Emergency County Hospital Sibiu, Sibiu, Romania; \\ ${ }^{3}$ Department of Anesthesia, University Emergency County Hospital Sibiu, Sibiu, Romania
}

SUMMARY - Therapeutic plasma exchange (TPE) is an extracorporeal blood purification technique, which removes large molecular weight particles such as autoantibodies from plasma. TPE is accepted by the American Society for Apheresis as first line treatment for some severe neuroimmune disorders. Double filtration plasmapheresis (DFPP) is a newer technique in which plasma is not entirely removed, only the antibodies, using special filters. High-dose intravenous immunoglobulins are an alternative treatment for these patients but are much more expensive. We reviewed medical records of 20 patients with severe neurological diseases requiring TPE or DFPP. We analyzed the indications, complications and efficacy of these procedures. After completing the procedures, neurological improvement was recorded in $80 \%$ of the patients, $5 \%$ had no improvement, and the mortality was $15 \%$. The rate of neurological improvement was similar to other studies. None of the patients presented catheter related complications. Systemic complications were mild, transient and completely reversible.

Key words: Plasma exchange; Plasmapheresis; Immunoglobulins, intravenous; Autoimmune diseases of the nervous system

\section{Introduction}

Therapeutic plasma exchange (TPE) is an extracorporeal blood purification technique designed to remove large molecular weight particles from plasma. The principal mechanism of action consists of removing circulating autoantibodies, immune complexes, cytokines, monoclonal proteins, toxins and other inflammatory mediators ${ }^{1}$.This procedure is clinically available from the early 1970s for the treatment of several neuroimmune disorders ${ }^{2}$. Removing these pathogenic substances from patient plasma, in recent years this procedure has been increasingly indicated for hematologic, neurological, connective tissue, nephrologic and

Correspondence to: Maria-Gabriela Catană, Department of Neurology, University Emergency County Hospital Sibiu, Pompeiu Onofreiu Str., 550166 No. 2-4, Sibiu, Romania

E-mail: catanamariagabriela@gmail.com

Received May 30, 2018, accepted January 7, 2019 metabolic disorders ${ }^{3}$. Double filtration plasmapheresis (DFPP) is a newer technique in which plasma is not entirely removed, only the antibodies, using special filters. Recent reports claim TPE to have numerous immunomodulatory effects ${ }^{4}$. Plasmapheresis is accepted as first line treatment, according to the American Society for Apheresis (ASFA) 2013 guidelines $^{3}$, for the following neuroimmune disorders: Guillain-Barré syndrome (GBS), myasthenia gravis in severe crisis, chronic inflammatory demyelinating polyneuropathy and fulminant forms of Wilson disease. Plasmapheresis is accepted as second line therapy in Lambert-Eaton myasthenic syndrome, multiple sclerosis relapsingremitting form, acute disseminated encephalomyelitis (ADEM) and in neuromyelitis optica (NMO) unresponsive to high-dose corticosteroids.

High-dose intravenous immunoglobulins (IVIG) represent an alternative treatment for severe neuroimmune disorders. According to ASFA guidelines, the 
efficiency is equal for both treatments ${ }^{3}$. Many physicians prefer IVIG because administration is easy, safe and involves few complications ${ }^{5,6}$, but IVIG is very expensive and is not covered by governmental health insurance in many countries ${ }^{7,8}$.

\section{Materials and Methods}

We retrospectively reviewed medical records of 20 patients with severe autoimmune neurological diseases requiring TPE or DFPP, treated in our hospital during a 4-year period (from November 2012 to December 2016). We analyzed the indications, side effects, complications and efficacy of those procedures in these patients. The study was approved by the Ethics Board of the County University Emergency Hospital Sibiu (SCJU Sibiu). All patients signed an informed consent form prior to the procedure (after the procedural risks being explained in detail by a senior physician).

The patients were admitted to the Intensive Care Unit (ICU) until the procedures were over. The right internal jugular vein was catheterized with a $20 \mathrm{~F}$ double lumen catheter in 18 patients and the left internal jugular vein was catheterized with a $20 \mathrm{~F}$ double lumen catheter in two patients. This procedure was performed under local anesthesia, with an aseptic technique. X-ray control was performed to assure proper position of the catheter.

To remove autoantibodies, we used 2 techniques, TPE and DFPP, using the HF440 machine (Infomed SA, Geneva, Switzerland) for both. Cascade filtration is a 2-step process during which plasma is first extracted from the blood and then circulated through a second filter, plasma fractionator. Having a membrane pore size approximately 10 -fold smaller than a plasmafilter, the plasma fractionator retains larger molecules such as immunoglobulin $\mathrm{G}(\mathrm{IgG})$, low-density lipoprotein (LDL)-cholesterol and viruses. The plasma is filtered and then returned to the patient, thus avoiding or minimizing the need for replacement fluids. The process can be named double filtration or DFPP (Double Filtration PlasmaPheresis).

The extracted plasma volume was calculated individually, using Nadler's formula and hematocrit, in a range of 1.5 total plasma volume/session. For TPE, we used a Granopen 060 Plasmafilter (Infomed SA, Geneva, Switzerland). As volume replacement fluids, we used a mixture of fresh frozen plasma (FFP) 800-900
mL, hydroxy ethyl starch (HES) 6\% solution $1000 \mathrm{~mL}$ and $4 \%$ solution of human albumin $(20 \%$ solution diluted in saline) to make up to the desired volume. DFPP was performed using a Granopen 060 Plasmafilter and Medopen 30 Plasmaseparator (Infomed SA, Geneva, Switzerland), with no necessity of replacement fluids. A session was usually performed within 2.5 to 6 hours depending on blood flow through the machine and plasma exchange rate, and repeated every 24-48 hours depending on the neurological status.

\section{Results and Discussion}

Twenty patients were included in the study and a total of 62 TPE procedures and 14 DFPP sessions were performed (Table 1). Of these 20 patients, 11 (55\%) were women and nine (45\%) were men, median age 56 (range 13-85) years, with the following diagnoses: GBS in nine (45\%), myasthenia gravis (MG) in four (20\%) patients, neuromyelitis optica (NO) in one (5\%) and chronic inflammatory demyelinating polyradiculoneuropathy (CIDP) in one (5\%) patient. The remaining $25 \%$ of patients had the following diagnoses: stiff-man syndrome, transverse myelitis, progressive form of multiple sclerosis, NMO spectrum disorders and West-Nile encephalitis in one patient each.

Ten $(50 \%)$ of the 20 patients were treated with TPE and three (15\%) with DFPP as first-line therapy, whereas nine $(45 \%)$ patients received TPE and four (20\%) received DFPP as second-line therapy. The mean number of TPE sessions/patient and DFPP sessions/patient was 3.8 (range 3-4) and 2.5 (range 2-3), respectively. For TPE, a total of 219 human albumin $20 \%$ solution vials and 274 bags of FFP were used as replacement fluids. Eight patients having benefited from TPE and DFPP sessions received steroid medication before plasma exchange (three patients with MG and one patient with CIDP, multiple sclerosis, stiff-man syndrome, NMO and NMO spectrum disorders each). Other therapies (IVIG or immunosuppressive medication) were not used before administration of plasma exchange therapy (Table 2).

A total of 25 systemic complications associated with TPE and DFPP were recorded (Table 3). There were no local complications related to the central venous catheter. The most common systemic complications of plasma exchange were hypocalcemia in nine 
Table 1. Number of TPE and DFPP sessions according to patient diagnoses

\begin{tabular}{|l|l|l|l|l|l|l|}
\hline Diagnosis & $\begin{array}{l}\text { GBS } \\
(\mathrm{n}=9)\end{array}$ & $\begin{array}{l}\text { CIDP } \\
(\mathrm{n}=1)\end{array}$ & $\begin{array}{l}\text { MG } \\
(\mathrm{n}=4)\end{array}$ & $\begin{array}{l}\text { NMO } \\
(\mathrm{n}=1)\end{array}$ & $\begin{array}{l}\text { Other } \\
(\mathrm{n}=5)\end{array}$ & $\begin{array}{l}\text { Total } \\
(\mathrm{N}=20)\end{array}$ \\
\hline Age (median) & 59 & 57 & 54 & 58 & 48 & 56 \\
Sex (F/M) & $3 / 6$ & $1 / 0$ & $2 / 2$ & $1 / 0$ & $4 / 1$ & $11 / 9$ \\
TPE as first-line therapy (n) & 8 & - & 1 & - & 1 & 10 \\
TPE as second-line therapy (n) & 1 & 1 & 2 & 1 & 4 & 9 \\
Total TPE sessions (n) & 30 & 3 & 11 & 4 & 14 & 62 \\
DFPP as first-line therapy (n) & 1 & - & - & 1 & - & 2 \\
DFPP as second-line therapy (n) & 2 & - & 1 & - & 1 & 4 \\
Total DFPP sessions (n) & 7 & - & 3 & 1 & 3 & 14 \\
TPE session/patient (mean) & 4 & 3 & 3.5 & 4 & 4 & 3,8 \\
DFPP session/patient (mean) & 3 & - & 3 & 2 & 2 & 2.5 \\
\hline
\end{tabular}

$\mathrm{TPE}=$ therapeutic plasma exchange DFFP = double filtration plasmapheresis; GBS = Guillain-Barre syndrome; CIDP = chronic inflammatory demyelinating polyneuropathy; $\mathrm{MG}=$ myasthenia gravis; $\mathrm{NMO}=$ neuromyelitis optica; $\mathrm{FFP}=$ fresh frozen plasma

Table 2. Use of steroid therapy, IVIG and replacement fluids according to patient diagnoses

\begin{tabular}{|l|l|l|l|l|l|l|}
\hline Diagnosis & $\begin{array}{l}\text { GBS } \\
(\mathrm{n}=9)\end{array}$ & $\begin{array}{l}\text { CIDP } \\
(\mathrm{n}=1)\end{array}$ & $\begin{array}{l}\text { MG } \\
(\mathrm{n}=4)\end{array}$ & $\begin{array}{l}\text { NMO } \\
(\mathrm{n}=1)\end{array}$ & $\begin{array}{l}\text { Other } \\
(\mathrm{n}=5)\end{array}$ & $\begin{array}{l}\text { Total } \\
(\mathrm{N}=20)\end{array}$ \\
\hline $\begin{array}{l}\text { Responsive to treatment (n) } \\
\text { Steroid }\end{array}$ & 8 & 1 & 3 & 1 & 3 & 16 \\
IVIG & 0 & 1 & 3 & 1 & 3 & 8 \\
Replacement fluid (vials, $\mathrm{n})$ & - & - & - & - & - & - \\
Albumin & 100 & 6 & 57 & 13 & 43 & 219 \\
FFP & 143 & 14 & 47 & 18 & 52 & 274 \\
\hline
\end{tabular}

IVIG = intravenous immunoglobulin; FFP = fresh frozen plasma; GBS = Guillain-Barre syndrome; CIDP = chronic inflammatory demyelinating polyneuropathy; $\mathrm{MG}=$ myasthenia gravis; $\mathrm{NMO}=$ neuromyelitis optica

Table 3. Complications according to patient diagnoses

\begin{tabular}{|l|l|l|l|l|l|l|}
\hline Diagnosis & $\begin{array}{l}\text { GBS } \\
(\mathrm{n}=9)\end{array}$ & $\begin{array}{l}\text { CIDP } \\
(\mathrm{n}=1)\end{array}$ & $\begin{array}{l}\text { MG } \\
(\mathrm{n}=4)\end{array}$ & $\begin{array}{l}\text { NMO } \\
(\mathrm{n}=1)\end{array}$ & $\begin{array}{l}\text { Other } \\
(\mathrm{n}=5)\end{array}$ & $\begin{array}{l}\text { Total } \\
(\mathrm{N}=20)\end{array}$ \\
\hline Catheter related & - & - & - & - & - & - \\
Hypocalcemia & 5 & - & 2 & 1 & 1 & 9 \\
Hyponatremia & 2 & 1 & 1 & - & - & 4 \\
Hypokalemia & 3 & - & 2 & - & - & 5 \\
Hypotension & 1 & - & - & - & 1 & 2 \\
Infections/sepsis & 2 & - & 2 & - & 1 & 5 \\
Total complications & 13 & 1 & 7 & 1 & 3 & 25 \\
Death & 1 & - & 1 & - & 1 & 3 \\
\hline
\end{tabular}

GBS = Guillain-Barre syndrome CIDP = chronic inflammatory demyelinating polyneuropathy $\mathrm{MG}=$ myasthenia gravis; $\mathrm{NMO}=$ neu romyelitis optica 
(36\%), hyponatremia in four (16\%) and hypokalemia in five (20\%) patients. These patients presented perioral and limb paresthesias and muscle cramps; these were mild and transient and never required interruption of the plasma exchange session. Mild, transient hypotension (systolic blood pressure $<100 \mathrm{~mm} \mathrm{Hg}$ ) occurred in two (8\%) patients, with minimal or no symptoms. Infection/sepsis (generated by prolonged immobilization) developed in five (20\%) patients. The complication rate was $32 \%$ in the total of $76 \mathrm{TPE}$ and DFPP sessions.

No patient death was recorded during the plasma exchange procedures. Three patients died from septic shock secondary to bronchopneumonia, including one patient with GBS, West-Nile encephalitis and MG (aspiration pneumonia) each, late in the evolution of the disease (Table 3).

After completing the plasma exchange sessions, $80 \%$ of the patients had clinical neurological improvement, $5 \%$ had no improvement, and the mortality was $15 \%$.

Guillain-Barré syndrome is a major cause of acute generalized paralysis; $5 \%$ of patients with severe evolution develop respiratory failure that requires endotracheal intubation and mechanical ventilation ${ }^{9}$. The primary pathogenesis is a presumed autoimmune attack on peripheral nerves ${ }^{10}$. In our study, we included nine patients with GBS with the following etiology: flu vaccine in one patient, enterocolitis in two patients and respiratory infections in six patients. International guidelines suggest TPE or IVIG as front line treatment for severe $\mathrm{GBS}^{3}$. On the one hand, the efficiency of TPE and IVIG in GBS (both being equally efficient) has been underlined by two Cochrane reviews ${ }^{9,11}$. On the other hand, IVIG treatment has proven to be twice as expensive in comparison with TPE, with similar clinical response ${ }^{12}$. A recent study published by Kumar $e t$ al. presents a group of 17 patients with GBS, each of them receiving TPE, $82.35 \%$ of these having a positive clinical outcome ${ }^{13}$. In another study reported by Hahn et al., the TPE procedure was applied to 15 patients with GBS and 12 (80\%) had good outcome ${ }^{14}$. In our study, we had nine patients with GBS, and eight $(88.8 \%)$ of them showed significant improvement after TPE, similar to the studies mentioned above.

Myasthenia gravis is another neuroimmune disorder, in which $15 \%$ to $20 \%$ of patients evolve with myasthenic crises $(\mathrm{MC})^{15,16} . \mathrm{MC}$ is defined as acute respi- ratory failure or bulbar weakness causing dysphagia, with a high risk of aspiration, requiring tracheal intubation at $\mathrm{ICU}^{16}$. Literature reports claim that TPE and IVIG are both equally efficient in $\mathrm{MC}^{17}$. Kumar $e t$ al. report on a success rate of TPE in 11 (84.6\%) of 13 patients with $\mathrm{MC}^{13}$. In our group, there were four $\mathrm{pa}^{-}$ tients with $\mathrm{MC}$, and three of them successfully recovered after TPE. Some studies support DFPP in treating $\mathrm{MC}^{18}$. In our group, one patient with $\mathrm{MC}$ was successfully treated with 3 DFPP sessions, applied every other day.

The patients with RRMS and NMO had a 5-year evolution of the disease with slight response to corticosteroids and multiple relapses. Among the autoantibodies that play a role in MS pathogenesis, most important are proteins involved in the composition of myelin sheath, i.e. myelin basic protein (MBP), myelin oligodendrocyte glycoprotein (MOG), myelin proteolipid protein (PLP) and myelin-associated protein (MAG), this being the reason why the ASFA 2013 guidelines recommend plasmapheresis as second-line therapy ${ }^{19}$. As far as NMO is concerned, the relapse treatment is IV methylprednisolone, and if it fails to improve the neurological status, plasma exchange must be considered. New studies even suggest combining IV methylprednisolone with plasma exchange in patients with severe disease ${ }^{20}$. The patient with myelitis was newly diagnosed and we decided to perform TPE due to the fact that his symptomatology did not respond to corticotherapy.

Kaynar et al. report on a study involving 57 patients with neurological disorders that received an average of $5 \mathrm{TPE}$, with general improvement in $82 \%$ of patients ${ }^{21}$. In our group of 20 patients, improvement was recorded in $80 \%$ of patients. They received a mean of 3.8 TPE sessions, every other day.

In the above studies, the complications of TPE and DFPP were either local (related to venous catheter) or systemic (related to the TPE or DFPP procedure). In our study group, none of the patients developed catheter related complications, while systemic complications were mild, transient and completely reversible, and did not require interruption of the procedure. Some patients complained of paresthesias and cramps due to electrolyte imbalances. According to the World Apheresis Registry Data 2003-2007, the incidence of these symptoms is $1.5 \%-9 \%$. 


\section{Conclusions}

The TPE and DFPP procedures provide first-line management in several neuroimmune disorders with severe evolution. In our study, the overall neurological improvement rate after TPE and DFPP procedures was $80 \%$, with mild and manageable complications and without death generated directly by these procedures. The alternative treatment to TPE and DFPP is high-dose IVIG, which is easy to administer but is more expensive and difficult to obtain in our hospital. To our knowledge, this report presents the largest study group in our country in which neurological patients were treated with TPE and DFPP. These therapeutic procedures are safe and efficient, provided that they are performed by experienced practitioners, and are much less expensive than IVIG while having the same efficiency.

\section{References}

1. Reeves HM, Winters JL. The mechanism of action of plasma exhange. Br J Haematol. 2014;164:342-51.

2. Strauss RG, Ciavarella D, Gilcher RO, Kasprisin DO, Kiprov DD, Klein HG, et al. An overview of current management. J Clin Apher. 1993;8:189-94. doi: 10.1002/jca.2920080402

3. Schwartz J, Winters JL, Padmanabhan A, Balogun RA, Delaney M, Linenberger ML, Szczepiorkowski ZM, Williams ME, Wu Y, Shaz BH. Guidelines on the use of therapeutic apheresis in clinical practice - evidence-based approach from the writing committee of the American Society for Apheresis: the sixth special issue. J Clin Apher. 2013;28(3):145-284, doi: 10.1002/jca.21276.

4. Burmester GR, Feist E, Dorner T. Emerging cell and cytokine targets in rheumatoid arthritis. Nat Rev Rheumatol. 2014; 10:77-88, doi: 10.1038/nrrheum.2013.168. Epub 2013 Nov 12.

5. Buraga I, Martin RE, Dobrescu A, Buraga I. Clinical response to intravenous immunoglobulin in acute inflammatory demyelinating inflammatory polyradiculoneuropathy. Farmacia. 2013:61(5):957-65.

6. Cojocaru M, Cojocaru IM, Negres S, Popa F, Purcarea VL, Arsene AL. Intravenous immunoglobulin therapy in neurological disease. Farmacia. 2011;59(6):737-41.

7. Bayry J, Kazatchkine MD, Kaveri SV. Shortage of human intravenous immunoglobulin: reasons and possible solutions. Nat Clin Pract Neurol. 2007;12:63-7.

8. Karaca S, Kozanoglu I, Karakurum Goskel B, Karatas M, Tan M, YerdelenVD, Giray S, Arlier Z. Therapeutic plasma ex- change in neurologic diseases: an experience with 91 patients in seven years. Archi Neuropsychiatry. 2014;51(1):63-8.

9. Raphael JC, Chevret S, Hughes RA, et al. Plasma exchange for Guillain-Barre syndrome. Cochrane Database Syst Rev. 2012; CD001798.

10. VanDoorn PA, Ruts L, Jacobs BC. Clinical features, pathogenesis and treatment of Guillain-Barre syndrome. Lancet Neurol. 2008;7:939-50.

11. Hughes RA, Swan AV, Van Doorn PA.. Intravenous immunoglobulin for Guillain Barre syndrome. Cochrane Database Syst Rev. 2014;CD002063, doi: 10.1002/14651858.CD002063.pub5

12. Winters JL, Brown D, Hazard E. Cost-minimization analysis of the direct costs of TPE and IVIG in the treatment of Guillain-Barre syndrome. BMC Health Serv Res. 2011;11:101, doi: 10.1186/1472-6963-11-101.

13. Kumar AS, Latha B, Dhivya K. Therapeutic plasma exchange in neuroimmunological disorder. Int J Res Med Sci. 2017;5(4): 1550-3, DOI: http://dx.doi.org/10.18203/2320-6012. ijrms20171263.

14. Hahn AF, Bolton CF, Pillay N, et al. Plasma exchange therapy in chronic inflammatory demyelinating polyneuropathy. A double-blind, sham-controlled, cross-over study. Brain. 1996: 119(pt 4):1055-66.

15. Gajdos P, Chvret S, Toyka K. Plasma exchange for myasthenia gravis. Cochrane Database Syst Rev. 2002;CD002275.

16. KeeseyJC. Clinical evaluation and management of myasthenia gravis. Muscle Nerve. 2004;29:484-505

17. Barth D, Nabavi Nouri M, $\mathrm{Ng}$ E, et al. Comparison of IVIG and PLEX in patients with myasthenia gravis. Neurology. 2011;76:2017-23, doi: 10.1212/WNL.0b013e31821e5505.

18. Yeh JH, Chiu HC. Comparison between double-filtration plasmapheresis and immunoadsorption plasmapheresis in the treatment of patients with myasthenia gravis. J Neurol. 2000; 247:510-3.

19. Lazibat I, Rubinić Majdak M, Županić S. Multiple sclerosis: new aspects of immunopathogenesis. Acta Clin Croat. 2018;57 (2):352-60. https://doi.org/10.20471/acc.2018.57.02.17

20. Roman-Filip C, Ungureanu A, Cernuşcă-Miţaru M. Painful tonic spasms and brainstem involvement in a patient with neuromyelitis optica spectrum disorder. Polish J Neurol Neurosurg. 2016;50(1):55-8. doi: 10.1016/j.pjnns.2015.10.010.

21. Kaynar L, Altuntas F, Aydogdu I, Turgut B, Kocyigit I, Hacioglu SK, et al. Therapeutic plasma exchange in patients with neurologic diseases; retrospective multicentric study. Transfus Apher Sci. 2008 Apr;38(2):109-15. doi: 10.1016/j.transci. 2007.11.002.

22. Stegmayr B, Ptak J, Wikstrom B, Berlin G, Axelsson CG, Griskevicius A, et al. World apheresis registry 2003-2007 data. Transfus Apher Sci. 2008;39:247-54, doi: 10.1016/j.transci.2008.09.003. 


\section{Sažetak}

\section{TERAPIJSKA IZMJENA PLAZME I PLAZMAFEREZA S DVOSTRUKIM FILTRIRANJEM U TEŠKIM NEUROIMUNIM BOLESTIMA}

\section{Roman-Filip, M-G. Catană, A. Bereanu, A. Lăzăroae, F. Gligor i M. Sava}

Terapijska izmjena plazme (TIP) je izvantjelesna tehnika pročišćavanja krvi kojom se iz plazme uklanjaju čestice velike molekularne težine poput autoantijela. Američko udruženje za aferezu prihvatilo je TIP kao liječenje prvog izbora za neke teške neuroimune bolesti. Plazmafereza s dvostrukim filtriranjem (PFDF) je nova tehnika kojom se ne uklanja sva plazma, nego samo antitijela, $i$ to pomoću specijalnih filtara. Visoke doze intravenskih imunoglobulina su alternativna terapija za ove bolesnike, ali su znatno skuplji. Pregledali smo medicinske zapise 20 bolesnika s teškim neurološkim bolestima koji su trebali TIP ili PFDF. Analizirali smo indikacije, komplikacije i učinkovitost ovih postupaka. Nakon završetka postupaka pobolǰsanje neurološkog statusa zabilježeno je u $80 \%$ bolesnika, $5 \%$ ih nije imalo nikakvo poboljšanje, a smrtnost je bila $15 \%$. Stopa neurološkog poboljšanja bila je slična onoj opisanoj u drugim istraživanjima. Komplikacije povezane s kateterom nisu zabilježene ni u jednog bolesnika. Sistemske komplikacije bile su blage, prolazne i u potpunosti reverzibilne.

Ključne riječi: Plazma, izmjena; Plazmafereza; Imunoglobulini, intravenski; Autoimune bolesti živčanog sustava 